\title{
Long Non-Coding RNAs: the New Horizon of Gene Regulation in Ovarian Cancer
}

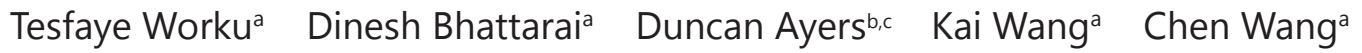 \\ Zia ur Rehman ${ }^{\mathrm{a}}$ Hira sajjad Talpura Liguo Yang ${ }^{\mathrm{a}}$
}

aKey Laboratory of Agricultural Animal Genetics, Breeding and Reproduction, Education Ministry of China, College of Animal Science and Technology, Huazhong Agricultural University, Wuhan, P. R. China; ${ }^{b}$ Centre for Molecular Medicine and Biobanking, University of Malta, Msida, Malta; 'Faculty of Biology, Medicine and Health, the University of Manchester, Manchester M1 7DN, UK

\section{Key Words}

LncRNA • Ovarian cancer • Biomarker • Therapy

\begin{abstract}
Long non-coding RNAs (IncRNAs), a class of non-coding transcripts, have recently been emerging with heterogeneous molecular actions, adding a new layer of complexity to generegulation networks in tumorigenesis. LncRNAs are considered important factors in several ovarian cancer histotypes, although few have been identified and characterized. Owing to their complexity and the lack of adapted molecular technology, the roles of most IncRNAs remain mysterious. Some IncRNAs have been reported to play functional roles in ovarian cancer and can be used as classifiers for personalized medicine. The intrinsic features of IncRNAs govern their various molecular mechanisms and provide a wide range of platforms to design different therapeutic strategies for treating cancer at a particular stage. Although we are only beginning to understand the functions of IncRNAs and their interactions with microRNAs (miRNAs) and proteins, the expanding literature indicates that IncRNA-miRNA interactions could be useful biomarkers and therapeutic targets for ovarian cancer. In this review, we discuss the genetic variants of IncRNAs, heterogeneous mechanisms of actions of IncRNAs in ovarian cancer tumorigenesis, and drug resistance. We also highlight the recent developments in using IncRNAs as potential prognostic and diagnostic biomarkers. Lastly, we discuss potential approaches for linking IncRNAs to future gene therapies, and highlight future directions in the field of ovarian cancer research.
\end{abstract}

\section{Introduction}

Ovarian cancer $(\mathrm{OC})$ is a gynecological malignancy that causes death in women worldwide. The epithelial ovarian cancer (EOC) subtype represents nearly $90 \%$ of all OC cases, contributing to $70 \%$ of all deaths caused by OC, because of the absence of early- 


\section{Cellular Physiology Cell Physiol Biochem 2017;44:948-966 \begin{tabular}{l|l|l}
\hline and Biochemistry 10.1159/000485395 & $\begin{array}{l}\text { C } 2017 \text { The Author(s). Published by S. Karger AG, Basel } \\
\text { www.karger.com/cpb }\end{array}$
\end{tabular} \\ Worku et al.: LncRNA: Future Biomarker and Therapy}

stage diagnostic tools [1-5]. In the United States, OC is the fifth most lethal malignancy in women, with 14, 000 estimated deaths and 22, 000 new cases occurring in 2016 [6]. Despite continuous efforts towards better treatment and/or improvement of the overall survival (OS) rates of patients, OC remains a threat to women because of drug resistance, the distinctive features of each OC subtype, and the lack of clear symptoms at early stages. Identification of biomarkers enabling diagnosis at the initial stage of OC and developing new therapies remain fundamental goals for researchers in the field of OC.

Continuous advancements in genomics technologies have revolutionized the world of RNA biology, particularly in the field of non-coding RNAs (ncRNAs), which has provided new research directions. As such, high-throughput sequencing technology has enabled the discovery of transcribed RNA molecules that lack protein-coding potential, but function beyond that in simply bridging DNA to protein through translational processes. Of ncRNAs, long non-coding RNAs (IncRNAs, greater than 200 nucleotides) are structurally complex transcripts that are involved in multiple cellular functions [7-9].

Continuous efforts have shed insights into the biological roles of lncRNAs in various normal and pathological physiological processes, such as development, metastasis, apoptosis, stem cell pluripotency, proliferation, DNA damage, differentiation, and cancer [9-18]. Unlike microRNAs (miRNAs) and other non-coding transcripts, lncRNAs are large and complex [19], and their ability to govern genes in virtually all transitional states is an indication of their potency. Indeed, IncRNAs control gene transcription epigenetically in combination with chromatin remodeling [3, 20-22], translation [23], splicing [24, 25], and post-translational stability [26].

The functional role of lncRNAs in almost all hallmarks of cancer is increasingly recognized and has augmented our knowledge, leading to a better understanding of the biology of different cancer types such as OC [27], hepatocellular carcinoma [28-31], endometrial cancer [32], lung [33-35], gliomas [36, 37], and prostate cancer [38, 39]. A few reports have demonstrated the classic involvement of IncRNAs in different OC stages with various modes of action, providing the opportunity to intervene at specific points in OC development [22, $40,41]$. Individual OC studies have described the involvements of some lncRNAs along with their prognostic and therapeutic relevance; however, many studies have not revealed an underlying mechanism. A previous genome-wide transcriptome study uncovered a link between cancer and lncRNAs [17].

Although the roles of only a few lncRNAs in virtually all features of OC cells have been uncovered, unforeseen roles and mechanisms of action will likely be discovered in the future. Hence, in this review, we provide a comprehensive view of the current literature highlighting prominent lncRNA biomarkers, as well as the strategies and therapeutic value of targeting lncRNAs to treat OC.

\section{LncRNA variants are associated with the risk and functionality of OC}

A handful of studies have identified non-coding genetic variants, such as singlenucleotide polymorphisms (SNPs), chromosomal rearrangements, and somatic copynumber alterations (SCNAs). However, less attention has been paid to ncRNA variants owing to the dogma that they are unable to transmit information and perform functional roles [42]; however, several studies have identified multiple SNPs in lncRNAs linked to the risk of developing OC $[14,43]$. Data from a recent study showed that SNPs are also capable of modulating the features of OC cells, suggesting that non-coding variants can potentially transmit cellular signals [44]. Notably, future work will define the algorithm through which ncRNAs contribute to OC cellular phenotypes.

A genome-wide association study (GWAS) identified an $\mathrm{A}>\mathrm{T}$ genetic variant in the exonic region of homeobox A11 antisense (HOXA11-AS) that was associated with a reduced risk for EOC. Further characterization of the identified genetic variant revealed that EOC cells carrying the minor allele $(\mathrm{T})$ showed reduced survival, migration, and invasion abilities 


\section{Cellular Physiology Cell Physiol Biochem 2017;44:948-966

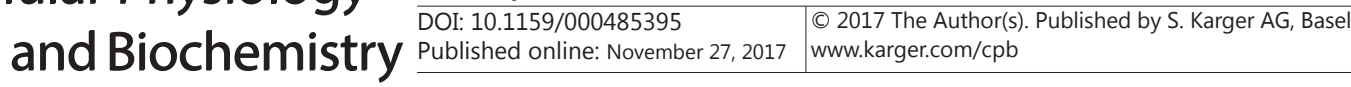 \\ Worku et al.: LncRNA: Future Biomarker and Therapy}

compared to EOC cells carrying the common allele (A) [44]. In a similar study, low HOXA11AS expression was found in OC cells, indicating its tumor suppressor property might be attributed to the T allele [44]. Thus, genetic variants of HOXA11-AS may play functional roles beyond being a risk factor for EOC. Such data provide impetus for further exploring the regulatory mechanisms of IncRNAs involved in cancer cell phenotypic changes.

An association study of Hox transcript antisense intergenic RNA (HOTAIR) polymorphisms and OC in a Chinese population reported that the rs4759314 and rs7958904 SNPs were associated with EOC susceptibility, although the clinicopathological features need to be defined. Moreover, individuals with $\mathrm{C}$ alleles for rs7958904 presented a low risk of acquiring EOC [14]. In a parallel study, Xue et al [45]. reported that the HOTAIR SNP rs7958904 was associated with a low risk of colorectal cancer. Another SNP of HOTAIR, rs920778 (C>T), which increases the risk of developing several cancer types such as breast and gastric cancers [46, 47], also appears to be linked to an increased risk for OC and poor prognosis [43]. These SNPs could be used as predictive tools for classifying individuals or populations susceptible to OC. Genetic variants of various lncRNAs can also predispose individuals to other pathologies other than cancer. For example, an SNP in the antisense non-coding RNA in the INK4 locus (ANRIL) lncRNA seems to be associated with increased risks for developing cardiovascular diseases, diabetes, and endometriosis. Nevertheless, the specific SNPs contributing to these diseases are awaiting further investigation [48].

SCNAs, which mainly occur in the non-coding genomic landscape [49], can contribute to carcinogenesis [50]. Pioneering analysis of segregated public databases has become a powerful tool for screening genomic regions harboring lncRNAs genes with SCNAs, which can induce cancer [51], mainly when genomic regions are deleted or amplified. One of the lncRNAs identified within SCNAs and suggested to drive cancer is focal amplified lncRNA on chromosome 1 (FAL1). This lncRNA was shown to play oncogenic roles, and its expression and copy-number alteration (CNA) are associated with OC clinical outcomes [22]. Liu et al. also identified 11 dysregulated IncRNAs, based mainly on their CNAs, which were associated with poor OS in breast cancer. Of these IncRNAs, LINC00657 lncRNA knockout was shown to suppress breast cancer cell growth and proliferation [52], indicating its oncogenic role. Collectively, these data reveal that genetic variants of lncRNAs may serve functional and predictive roles, despite some inconsistent results that urge further study in large cohorts. Hence, a deep understanding of how SNPs and CNAs regulate the expression of IncRNAs will have far-reaching implications in treating cancer and other diseases. Additionally, identification and characterization of genetic variants involved in the canonical biosynthesis of IncRNAs would provide vital information, leading to a comprehensive understanding of the roles of IncRNA variants in human cancers.

\section{Involvement of IncRNAs in OC}

Recent reports have indicated that, when dysregulated, numerous IncRNAs are involved in OC initiation, development, progression, and chemoresistance [27, 41]. Some recently identified and classic lncRNAs have been consistently reported to regulate OC tumorigenesis, either alone or in association with partner molecules, which are described herein.

Metastasis-associated lung adenocarcinoma transcript 1 (MALAT1), expressed from chromosome 11q13 and occupying an $8.7-\mathrm{kb}$ genomic area [53], is transcriptionally controlled by the tumor-suppressor p53 gene [54] and has been shown to modulate several cancer types, including OC. Up-regulation of MALAT1 promotes the migration, proliferation, metastasis, invasion, and growth of ovarian tumor cells in vivo [55-57]. Microarray analysis after RNA interference (RNAi)-mediated knockdown of MALAT1 expression showed that as many as 449 [55] or 921 [56] genes were transcriptionally regulated and enriched in terms of important OC cells features. In these studies, MALAT1 downregulation abrogated the aggressive behavior of OC cells by arresting cell cycle progression at G0/G1 leading to apoptosis, in vitro [55] and repressed tumor growth in vivo [56]. MALAT1 was significantly 
associated with metastasis and tumor size, and shown to regulate these phenomena through mitogen-activated protein kinase (MAPK) [57]. Although these studies primarily describe the downstream cellular effects of MALAT1 and fail to demarcate the associated mechanisms of actions, MALAT1 seems to be the major focus of therapy for patients with OC.

Of several IncRNAs implicated in OC malignancies, the mechanisms of actions of a few of them are identified and described below. Both overexpression and copy-number amplification of FAL1 are involved in OC. Mechanistic studies revealed that FAL1 is epigenetically associated with the BMI1 proto-oncogene, polycomb ring finger (BMI1), a class of polycomb repressive complexes (PRCs). FAL1 also guides BMI1 to the cyclindependent inhibitor $1 \mathrm{~A}(\mathrm{p} 21)$ gene locus (a tumor-suppressor gene), thereby inhibiting its transcription. This, in turn, promotes the primary cancer cell cycle progression and facilitates malignant transformation [22] (Fig. 1A). Data from recent studies have evidenced that cancer-associated fibroblasts (CAFs), the main constituent of tumor stroma, can promote carcinogenesis and contribute to drug-resistance in several cancer types, including OC [58, 59]. Recently, Zhao and co-workers implicated long intergenic non-protein coding RNA 92 (LINC00092) in CAF-mediated ovarian tumorigenesis and demonstrated its association with glycolysis regulation in cancer. As indicated in Fig. 1B, the glycolysis-regulatory molecules, fructose-2 and 6-biphosphatase (PFKFB2), bind to the binding site of LINC00092, leading to a reciprocal regulatory loop with CAFs by controlling glycolytic products to maintain the tumor environment and subsequently cancer metastasis [40].

Reduced expression of brain cytoplasmic RNA 200 (BC200; also known as brain cytoplasmic RNA1) and growth arrest-specific 5 (GAS5) has been observed in ovarian tumor tissues and cell lines $[60,61]$. Further inhibition of BC200 enhances the proliferative capacity of cancer cells in vivo [60], and overexpression of GAS5 offsets the aggressive behavior of OC cells both in vitro and in vivo [61]. Subsequent experiments revealed that GAS5 contributes to OC tumorigenesis through downstream effects on genes related to cell cycle progression, namely, $C D K N 1 A$, cyclin D1, and apoptotic protease-activating factor ( $A P A F A)$. The oncogenic functions of these lncRNAs seem to be favored at low expression, unlike most lncRNAs. In contrast to BC200 and GAS5, overexpression of ANRIL, colon cancer associated transcript 2 (CCAT2), taurine up-regulated gene 1 (TUG1), and C17/f90 promotes cancer cell proliferation, invasion, and migration. These lncRNAs were also reported to be associated with a high tumor grade and FIGO stage, and distant metastasis [62-65]. Subsequent microarray and in vitro analyses identified met proto-oncogene (MET) and matrix metalloproteinase 3 (MMP3) as downstream targets of ANRIL [63]; a pro-metastatic gene, c-myelocytomatosis (MYC) was targeted by C17/f90 [64]. TUG1 knockdown abrogated cancer cell phenotypes, reversed EMT, and initiated apoptosis, while epithelial makers and apoptosis-related proteins were dysregulated [65] in vitro, indicating that molecules downstream of TUG1could represent valuable therapeutic targets. However, further study is required to discern the molecular mechanisms underlying the function of these lncRNAs in OC.

The study undertaken by Richard et al [44]. indicated that HOAX11as functions as a tumor suppressor in OC cell lines and its expression was down-regulated in a cohort of 18 patients with EOC. However, this report has been challenged by Yim et al [66]., who observed that HOAX11as expression was up-regulated in a cohort of 129 patients with serous OC (SOC) and it promoted cell proliferation, metastasis, and invasion in vitro. Conversely, small interfering RNA (siRNA)-induced HOAX11as down-regulation impaired cancer cell phenotypes in vitro, concomitantly regulating angiogenesis, motility, and the epithelialmesenchymal transition (EMT) [66].

Contradictory results have been reported for sprouty 4 intronic transcript 1 (SPRY4IT1) lncRNA, where enhanced and low expression promoted OC progression and metastasis in a cohort of 124 [67] and 15 [68] patients with OC, respectively. In further experiments, SPRY4-IT1 promoted OC tumorigenesis by affecting cell cycle progression [67], and EMT and cell cycle processes [68]. Given the complexity of cancer cells, it is not surprising that a gene can act as an oncogene or tumor-suppressor in cells with the same histotypes. This observed discrepancy is likely attributable to mutations, sample sizes, and the techniques 
Fig. 1. Heterogeneity of the molecular mechanisms of action of lncRNAs in OC tumorigenesis. A. FAL1 interacts with BMI1, a component of PRC1, and promotes recruitment of the complex to the 21 promoter to suppress its transcription, leading to malignant transformation. B. IncRNA LINC00092 binds to the mRNA of PFKFB2 and promotes glycolysis, thereby providing feedback to CAFs for sustaining cancer tumor cells. FAL1, focally amplified IncRNA on chromosome 1; BMI1, BMI1 proto-oncogene, polycomb ring finger; PRC1, polycomb repressive complex 1; p21, cyclin-dependent inhibitor $1 \mathrm{~A}$; CAFs, cancerassociated fibroblasts; PFKFB2, fructose-2, 6-biphosphatase; LINC00092; long intergenic non-protein coding RNA 92.

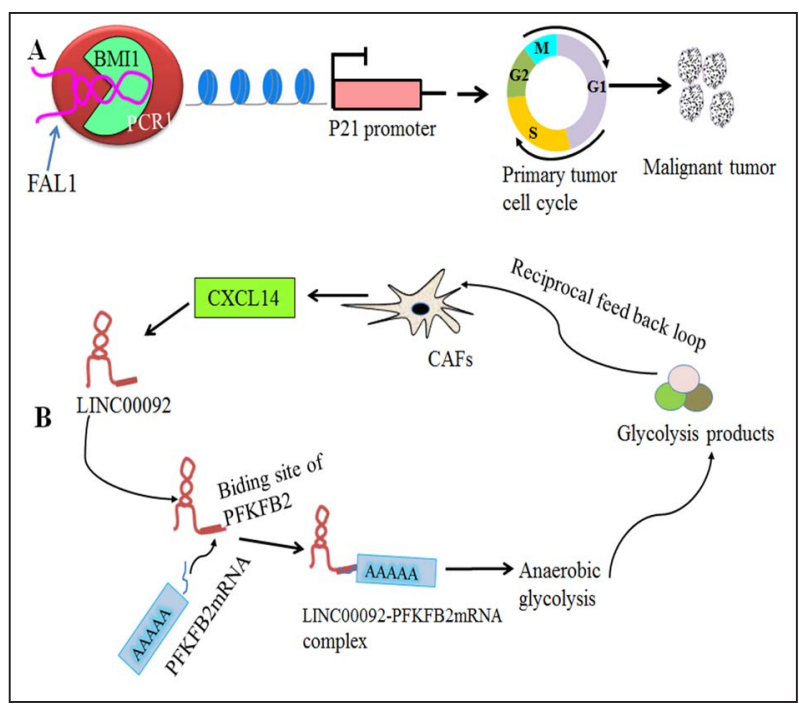

used. Studies using a large cohort of patient samples are warranted to clearly characterize these IncRNAs as either oncogenes or tumor-suppressors. The regulatory roles of lncRNAs in OC, explored in various studies are presented in Table 1, while their specific functions are discussed above.

\section{LncRNA signature as a diagnostic and prognostic biomarker of OC}

LncRNAs are considered potentially novel clinical tools for patient management owing to their tissue- and/or cell-specific expression patterns. Given their cell-specific expression, lncRNAs have been described as potential biomarkers in various cancers types such as gastric [72], lung [73], prostate [74], and hepatocellular carcinoma [75]. Similarly, several lncRNAs have been identified as potential biomarkers in cells with different OC histotypes, where their expressions levels are altered. In cases where dysregulated lncRNAs are associated with OC, IncRNAs might potentially serve as biomarkers, as summarized in Table 2 and discussed in detail below.

$\mathrm{Li}$ et al. attempted to assess the clinical relevance of C17orf91 IncRNA in OC, using public datasets deposited in the Gene Expression Omnibus database and noticed differential expression of $\mathrm{C} 17$ orf 91 between omental metastases and primary tumors. Subsequent in vitro evaluation indicated that C17orf91 can be employed as prognostic biomarker for patients with OC [64]. Similarly, meta-analysis of four independent datasets derived from 954 human samples of 4 different cancer types, including OC, revealed that higher expression of human urothelial carcinoma associated 1 (UCA1) was linked to reduced survival, suggesting UCA1 as a predictive biomarker [76]. Furthermore, $\mathrm{Hu}$ and colleagues identified a key oncogene IncRNA, FAL1, as a prognostic biomarker of OC by employing bioinformatics at the genomic scale [22].

Overexpression and methylation of the HOTAIR gene mediate the therapeutic resistance of OC cells; thus, HOTAIR is associated with poor OS [77]. Interestingly, as DNA is unlikely to change, HOTAIR DNA-based prognostic biomarkers could be used as reliable classifiers to distinguish patients for personalized treatment. Moreover, a recent meta-analysis of data from 13 studies revealed 8 up-regulated and 5 down-regulated lncRNAs associated with poor prognosis, and of these IncRNAs, higher expression of HOTAIR was associated with shorter OS in patients with OC [78].

Survival outcomes have been evaluated in several OC patients with dysregulated expression of lncRNAs. Among these, the prognosis associated with ANRIL, CCAT2, AB073614, 


\section{Cellular Physiology Cell Physiol Biochem 2017;44:948-966 \begin{tabular}{l|l|l} 
DOI: $101159 / 000485395$ & O 2017 The Author(s). Published by S. Karger AG, Basel \\
www.karger.com/cpb
\end{tabular} \\ Worku et al.: LncRNA: Future Biomarker and Therapy}

Table 1. Tumorigenic IncRNAs known to modulate ovarian cancer. ANRIL, antisense non-coding RNA in the INK4 locus; APAFA, apoptotic protease-activating factor; BC200, brain cytoplasmic RNA 200; CCAT2, colon cancer-associated transcript 2; CDKN1A,cyclin-dependent inhibitor 1A EMT, epithelial-mesenchymal transition; GAS5, growth arrest-specific 5; HOXA11as, homeobox a11 antisense; MALAT1, metastasisassociated lung adenocarcinoma transcript 1;SPRY4-IT1, sprouty 4 intronic transcript 1;TUG1, taurine up-regulated gene

\begin{tabular}{|c|c|c|c|c|c|}
\hline & & & Down-regulation promotes proliferation in vitro. & & \\
\hline BC200 & Intergenic & Downregulation & & Unknown & [60] \\
\hline C17or f91 & & Upregulation & $\begin{array}{l}\text { Down-regulation inhibits migration, invasion, and } \\
\text { viability in vitro. }\end{array}$ & Regulates pro-metastatic genes & [64] \\
\hline GAS5 & Bidirectional & Downregulation & $\begin{array}{l}\text { Overexpression represses migration, invasion, and } \\
\text { proliferation and promotes apoptosis in vitro, } \\
\text { while reducing tumor growth in vivo. }\end{array}$ & $\begin{array}{l}\text { CDKN1A, cyclin D1, and APAFA are } \\
\text { downstream targets. }\end{array}$ & [61] \\
\hline HOXA11 as & & Downregulation & $\begin{array}{l}\text { Down-regulation attenuates migration, invasion, } \\
\text { and proliferation in vitro. }\end{array}$ & $\begin{array}{l}\text { Modulates motility and angiogenesis- } \\
\text { related genes }\end{array}$ & [66] \\
\hline $\begin{array}{l}\text { NR- } \\
026689\end{array}$ & & Upregulation & $\begin{array}{l}\text { Down-regulation suppresses migration and } \\
\text { invasion, and induces apoptosis in }\end{array}$ & Regulates apoptotic proteins & [71] \\
\hline \multirow{2}{*}{ SPRY4-IT1 } & & Upregulation & Down-regulation inhibits proliferation. & $\begin{array}{l}\text { Down-regulation arrests the cell cycle at } \\
\qquad \text { G0/G1 phase. }\end{array}$ & [67] \\
\hline & & Downregulation & $\begin{array}{l}\text { Overexpression enhances apoptosis and cell cycle } \\
\text { progression. }\end{array}$ & $\begin{array}{l}\text { Regulates expressions of EMT- } \\
\text { associated genes }\end{array}$ & [68] \\
\hline TUG1 & Intergenic & Upregulation & $\begin{array}{l}\text { Knockdown promotes apoptosis, inhibits } \\
\text { proliferation, and halts EMT in vitro. }\end{array}$ & $\begin{array}{l}\text { Regulates apoptosis-related proteins } \\
\text { and EMT factors }\end{array}$ & [65] \\
\hline
\end{tabular}

NEAT1, and GAS5 has been studied in patients with OC. For example, poor prognosis (shorter OS) is associated with high expression of nuclear paraspeckle assembly transcript 1 (NEAT1) [79], ANRIL [63], and AB0736614 in patients with OC [69]. Furthermore, both shorter OS and disease-free survival (DFS) were associated with up-regulated CCAT2 [62] and HOXA11as [66], whereas low expression of GAS5 was associated with shorter OS and DFS in patients with OC [61]. Another IncRNA, SPRY4-IT1, was found to be highly expressed in OC and could be used as an independent prognostic agent for OS and PFS, and a diagnostic marker for tumors in patients with OC [67]. 
Table 2. IncRNAs associated with OC clinical outcomes. ANRIL, antisense non-coding RNA in the INK4 locus; CCAT2, colon cancer-associated transcript 2; GAS5, growth arrest-specific 5; HOTAIR, hox transcript antisense intergenic RNA; HOXA11as, homeobox AS11 antisense; NEAT1, nuclear paraspeckle assembly transcript 1; UCA1, urothelial carcinoma associated; $\downarrow=$ low expression; $\uparrow=$ high expression.

\begin{tabular}{|c|c|c|c|c|}
\hline IncRNA & $\begin{array}{l}\text { Involved cases vs. normal } \\
\text { (no.) }\end{array}$ & Marker type & Observed clinical information & Ref \\
\hline АВ073614 & $\begin{array}{l}\text { Case-control (75 patients } \\
\text { with OC vs. } 75 \text { normal } \\
\text { subjects) }\end{array}$ & Prognostic & $\uparrow A B 073614$ was associated with shorter OS. & {$[69]$} \\
\hline ANRIL & $\begin{array}{l}\text { Case-control (38 patients } \\
\text { with SOC vs. } 30 \text { normal } \\
\text { subjects) }\end{array}$ & $\begin{array}{c}\text { Prognostic and } \\
\text { metastasis }\end{array}$ & $\begin{array}{l}\text { ^ANRIL was associated with shorter OS and } \\
\text { positively correlated with lymph node metastasis, } \\
\text { advanced FIGO, and high histological grade. }\end{array}$ & {$[63]$} \\
\hline ССAT2 & $\begin{array}{l}\text { Case-control (109 } \\
\text { patients with OC vs. } 45 \\
\text { normal subjects) }\end{array}$ & Prognostic & $\begin{array}{c}\text { ^CCAT2 was associated with shorter OS and DFS and } \\
\text { positively correlated with tumor grade, FIGO, and } \\
\text { distant metastasis. }\end{array}$ & {$[62]$} \\
\hline C17or f91 & $\begin{array}{l}\text { Case-control ( } 9 \text { patients } \\
\text { with OC vs. } 9 \text { normal } \\
\text { subjects) }\end{array}$ & Prognostic & ^C17orf91 was associated with shorter PFS and OS. & {$[64]$} \\
\hline GAS5 & $\begin{array}{l}\text { Case-control (63 patients } \\
\text { with OC vs. } 63 \text { normal } \\
\text { subjects) }\end{array}$ & Prognostic & $\begin{array}{c}\downarrow \text { GAS5 was associated with shorter OS and DFS and } \\
\text { negatively correlated with tumor size, depth of } \\
\text { invasion, and TNM stage. }\end{array}$ & {$[61]$} \\
\hline HOTAIR & $\begin{array}{l}\text { Case-control (68 patients } \\
\text { with OC vs. } 30 \text { normal } \\
\text { subjects) }\end{array}$ & $\begin{array}{c}\text { Prognostic and } \\
\text { diagnostic }\end{array}$ & $\begin{array}{c}\text { 个HOTAIR was associated with poor OS and positively } \\
\text { correlated with high histological grade, advanced } \\
\text { FIGO, and tumor size. }\end{array}$ & [3] \\
\hline HoXA11as & $\begin{array}{l}\text { Case-control (129 } \\
\text { patients with SOC vs. } 38 \\
\text { normal subjects) }\end{array}$ & Prognostic & $\uparrow$ HOXA11as was associated with shorter OS and PFS. & {$[66]$} \\
\hline NEAT1 & $\begin{array}{l}\text { Case-control (149 } \\
\text { patients with OC vs. } 149 \\
\text { normal subjects) }\end{array}$ & Prognostic & $\begin{array}{l}\text { TNEAT1 was associated with shorter OS and } \\
\text { positively correlated with tumor grade, FIGO stage, } \\
\text { and distant metastasis. }\end{array}$ & {$[79]$} \\
\hline UCA1 & $\begin{array}{c}\text { Meta-analysis of } 117 \text { OC } \\
\text { studies }\end{array}$ & Prognostic & TUCA1 was associated with shorter PFS and OS. & {$[76]$} \\
\hline
\end{tabular}

In attempting to identify and characterize an OC biomarker for prognosis based on an IncRNA expression signature, Zhou et al. utilized publicly available data from 544 patients with OC and identified 8 IncRNAs, which were used to stratify patients into different risk statuses. Furthermore, these IncRNAs and their prediction outcomes were associated with chemotherapy responses and BRCA1/2-mutated and BRCA1/2 wild-type tumors, suggesting 


\section{Cellular Physiology Cell Physiol Biochem 2017;44:948-966

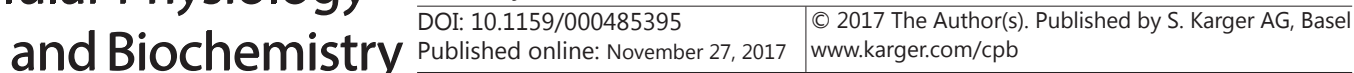 \\ Worku et al.: LncRNA: Future Biomarker and Therapy}

that these lncRNAs are independent biomarkers and therefore instrumental for identifying patients who may respond well to chemotherapy and those for whom alternative treatments should be prescribed [80].

Similarly, Martini and colleagues identified a molecular signature of 4 lncRNAs (PVT1, lnc-SERTD2-3, lnc-SOX4-1, and lnc-HRCT1) in tumor biopsies from a cohort of 202 patients with stage-I EOC, whose expressions were associated with risk of relapse. Of these lncRNAs, based on the expressions of PVT1 and lnc-SERTD2-3 together with hsa-miR-200c-3p, a risk score was derived to cluster patients into different risk statuses based on the median cutoff value, and patients with high and low risks had OS of 36 and 123 months, respectively (OR $=15.55,95 \% \mathrm{CI}=3.8-63.36)$ [81]. These lncRNAs provide an immense contribution for the early detection of EOC which has been a major hurdle associated with this disease, emphasizing the ability of the integrated use of biomarkers to improve prognosis or diagnostic performance. In support of this view, better diagnostic performance was attained when SPRY4-IT1, NEAT1, and ANRIL expressions were combined than when each was analyzed separately in non-small-cell lung cancer [82].

Owing to their clinical significance, it is essential to detect lncRNAs in bodily fluids of patient with OC and define their expression and stability, in order to employ them as biomarkers. In favor of this prospect, although no IncRNAs were reported in the bodily fluids of patient with OC, recent studies have identified elevated plasma lncRNA levels in patients with other cancer types such as non-small-cell lung cancer [83], hepatocellular carcinoma [84], thyroid cancer with lung metastases [85], esophageal squamous cell carcinoma [86], and renal cell carcinoma [87].

\section{Targeting IncRNA and miRNA networks for therapeutic development}

The post-transcriptional interaction between miRNAs and the mRNAs of target genes modulates gene expression, thereby determining the fate of cells in many normal and pathological processes, which has attracted the interest of pharmaceutical industries. In the past 15 years, numerous miRNAs have been identified in the human genome and are implicated in various cellular functions $[88,89]$. The functional involvement of miRNAs in OC initiation, development, and spread has been widely demonstrated. Furthermore, their potential use as biomarkers and for therapy has also been explored [90-93]. Most miRNAs play crucial cellular roles, participating in almost all molecular signaling pathways known to regulate cancer cell initiation, progression, metastasis, and survival. Currently, the development of miRNA-based therapy appears to be very promising. However, such therapy will likely be challenged by the mode of delivery to the intended organ, tissue, and cells, as well as by potential off-target effects. Like the interactions between miRNAs and mRNAs, the interactions between IncRNAs and miRNAs have been reported in the pathogenesis of several cancers, including OC [94, 95], gastric [96], hepatocellular carcinoma [97]. Understanding of the interactions between IncRNAs and miRNAs, and their subsequent impacts on the target molecules may facilitate an immense use of lncRNAs as therapeutic targets in future therapies.

Some miRNAs originate from non-coding genomic sequences and, of these, nearly $10 \%$ are harbored in lncRNA genes [98]. Many lncRNAs interact with miRNAs either by sequestering, harboring, or blocking them (Fig. 2A3, 2A1, and 2A2), thereby regulating the transcriptional activities and expression of target genes, which in turn leads to OC development and progression [94, 99]. However, miRNA binding to lncRNAs can dysregulate their expression, thereby controlling OC cell functions [26]. The oncogenic or tumorsuppressor effects of some (but not all) lncRNAs are partially or fully dependent on miRNAs, suggesting that endogenous competing RNA is significant in OC. Given the importance of the miRNA-lncRNA axis in OC, targeting lncRNA-miRNA networks is of interest for developing effective therapeutics. The imprinted, maternally expressed transcript, H19, is among the most studied lncRNA in normal cellular physiology and in carcinogenesis. H19 is involved 
Fig. 2. Schematic overview of IncRNA-miRNA biogenesis and routes of interaction. A. miRNA biogenesis from miRNA host gene. A1. An lncRNA binding miRNAs and guides them to their sites of action. A2. An lncRNA blocking the transport of miRNAs and preventing their activities. A3. An lncRNA sequestering miRNAs and isolating them, inhibiting their activity. B. LncRNA genes are transcribed and processed to IncRNAs and miRNAs. B1. miRNAs destabilize lncRNAs and regulate OC.

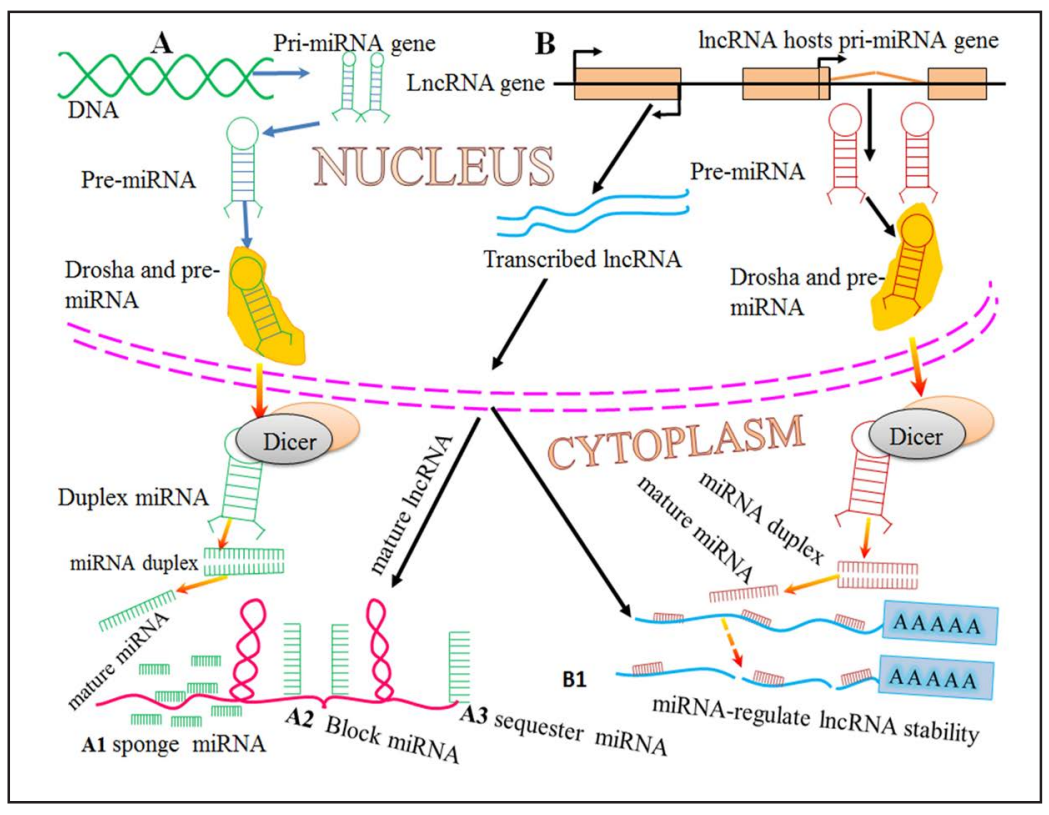

in multiple cancers and exerts its cellular effect by interacting with miRNAs. H19 activation promotes the migration and invasion of OC cells. Intriguingly, these events can be modulated by inhibiting let-7 to subsequently enhance expression of the target genes, HMGA2, $C-M Y C$, and IGF2BP, which can promote metastasis and activate downstream targets [94]. Human OC-specific transcript 2 (HOST2) is highly expressed in ovarian tumor tissue and promotes carcinoma cell line migration, invasion, and proliferation in vitro and tumor growth in vivo. A gain and loss-of-function study revealed that HOST2 down-regulation caused up-regulation of let-7, a tumor suppressor, leading to inhibited oncogenic behavior of OC cells and reduced tumor growth. Concomitantly, the expression levels of four let-7b target genes, namely c-MYC, HMGA2, IMP3, and double-stranded RNA-specific endoribonuclease (DICER), were down-regulated both at the mRNA and protein levels. Furthermore, HOST2 overexpression resulted in the up-regulation of MYC, HMGA2, DICER, and IMP3 at the protein and mRNA levels, indicating that HOST2 acts as a sequestering agent (Fig. 2A3) and subsequently suppresses the levels of let-7b to prevent binding to the 3 '-untranslated regions of its target mRNAs [99]. The observed phenomena strongly indicate that both HOST2 and let-7b can be targeted to develop a combination therapy.

Aberrant expression of HOTAIR is linked to OC. Like HOST2, HOTAIR overexpression promotes oncogenic OC cell behavior. The expression level of miRNA-373 increased following HOTAIR knockdown, thereby suppressing the viability, migration, and proliferation of OC cells. HOTAIR overexpression inhibited the activity of miRNA-373 and restored the behavior of cancer cells by acting as an endogenous sponge and regulating the Ras-relatedprotein, RAB-22 (RAB22A) [100]. Occasionally, miRNAs regulate the expression of IncRNAs, controlling their function as IncRNAs do. Higher expression of NEAT1 has been observed in both OC cell lines and tumors at the same time the expression levels of 124-p and HuR (a protein-binding RNA) were decreased and increased, respectively [26]. Mechanistically, HuR stabilizes NEAT1 expression, whereas 124-p suppresses it [26]. As discussed above, the actions and interactions of the identified lncRNAs and miRNAs in OC provide compelling evidence calling for the design of combination therapies, as patients may benefit from the additive or synergetic effects of both entities. In this context, a particular oncogene could be targeted by silencing both miRNAs and IncRNAs. Notably, following siRNA-mediated downregulation of ephrin type-A receptor-2 (EphA2), an ovarian oncogene, tumor growth was reduced, and this effect was amplified by additional inhibition of EphA2 by its target miRNAs [101], strongly demonstrating the potential importance of combination treatment. 


\section{Cellular Physiology Cell Physiol Biochem 2017;44:948-966 \begin{tabular}{l|l|l} 
DOI: 10.1159/000485395 & $\begin{array}{l}\text { (c) 2017 The Author(s). Published by S. Karger AG, Basel } \\
\text { www.karger.com/cpb }\end{array}$
\end{tabular} Worku et al.: LncRNA: Future Biomarker and Therapy}

\section{Targeting IncRNAs by CRISPR/Cas-9 for therapy}

The clustered regularly interspaced palindromic repeats (CRISPR)/Cas-9-based approach for genome editing has been ubiquitously used for wide applications in various model organisms. Despite its usefulness in functional studies of the non-coding genome, it has mainly been leveraged to study coding transcripts. Nevertheless, a few functional studies (silencing, activation, and knockout) of IncRNAs using CRISPR/Cas-9 have been reported. In human cell lines, CRISPR-mediated knockout of IncRNAs such as UCA1, AK023948, and IncRNA 21A has been achieved [102]. Of these IncRNAs, UCA1 promoted tumorigenesis and drug resistance in OC cells $[76,103]$, indicating that it can be targeted by CRISPR. Moreover, inhibiting UCA1 expression by double-guided RNA CRISPR/Cas-9 impaired bladder cancer cell phenotypes in vitro. In another study, high-throughput genomic deletion of IncRNAs was achieved by using paired-guide RNA CRISPR/Cas-9, leading to the identification of as many as 51 functional lncRNAs in human cancer cells on the genomic scale [104]. Taken together, these findings indicate that lncRNAs can potentially be targeted as an OC-treatment option using the CRISPR/Cas-9 system.

More importantly, in a recent study, Liu and colleagues identified and successfully inhibited nearly 500 lncRNA loci capable of amending cell proliferation by CRISPR-based interference approaches [105]. Indeed, this approach could be extended to identify and target other lncRNA loci associated with high carcinoma cellular features such as tumor expansion, EMT, and metastasis. A remarkable feature of the CRISPR/Cas-9 system is its ability to induce site-specific genomic edition with proper design. Thus, an SNP of HOXA11AS [44] (involved in ovarian tumor development and progression) and an SNP of HOTAIR lncRNA [106] (associated with EOC risk), could be targeted by the CRISPR/Cas-9 system. The CRISPR/Cas-9 system can be used to generate true knockouts of alleles that are functionally involved in OC phenotypic alterations and/or predisposing factors for OC. However, the application of CRISPR/cas-9 to some, but not all, lncRNA regions is challenging because it also dysregulate adjacent genes, leading to risk of disease occurrence. A genomic-wide analysis study revealed that, from 15, 929 lncRNAs, as few as 6, 053 were safely accessible by CRISPR/Cas-9, indicating that targeting lncRNAs in a complex genomic region requires additional approaches that favorably couple with CRISPR/Cas-9 [107]. Additionally, it was previously reported that CRISPR/Cas-9 can span away from the targeted genomic boundary and generate mutations in several model organisms [108, 109], suggesting that accurate CRISPR/Cas-9 targeting is crucial for effectively utilizing it as a genomic editing tool and keep organisms as safe as possible, following gene editing.

\section{Inhibition of chromatin-associated IncRNAs as a therapeutic approach}

LncRNAs have various modes of actions in ovarian carcinogenesis, including the interaction with chromatin-remodeling complexes to silence target genes. This phenomenon can be considered to represent a classical mechanism of action in ovarian tumorigenesis. The following lncRNAs function through chromatin remodeling: HOTAIR [3], FAL1 [22], H19 [110], X-inactive specific transcript (XIST) [111], and maternally expressed 3 (MEG3) [112]. Hence, it is reasonable to identify and target lncRNA-mediated chromatin complexes. In OC, expression of the BMI and EZH2 polycomb group protein complexes is mediated by lncRNAs; therefore, they can be either silenced or inhibited by synthetic inhibitors. DZNep was the first inhibitor developed to counter the malignant activity of EZH2 [113], but treatment with DZNep also caused the lysis of other components of polycomb repressive complex 2 (PRC2). In contrast, EPZ005687 [114], GSK126 [115], and EIP [116] specifically inhibit EZH2, suggesting that the oncogenic behavior of IncRNAs associated with EZH2 such as MEG3, H19, and HOTAIR can be reversed. 


\section{Cellular Physiology Cell Physiol Biochem 2017;44:948-966 and BiOChemistry Published online: November 27, 2017 \begin{tabular}{l|l} 
DOI: 10.1159/000485395 2017 The Author(s). Published by S. Karger AG, Basel \\
www.karger.com/cpb
\end{tabular} Worku et al.: LncRNA: Future Biomarker and Therapy}

\section{Silencing IncRNAs using RNAi techniques}

As described in this review and elsewhere in the literature, dysregulated lncRNAs contribute to OC initiation, tumorigenesis, and metastasis and the vast majority of lncRNAs share these features. For example, HOXA11AS, UCA1, NEAT1, HOTAIR, and SPRY4-IT1 overexpression contributes to OC development. The oncogenic roles of these lncRNAs could be directly inhibited by employing RNAi techniques, as recently reviewed [28], suggesting remarkable promise as targets for future therapeutic development.

\section{LncRNAs and partner molecules mediate drug-resistance in OC}

The resistance of tumor cells to multiple therapeutic approaches remains the biggest barrier for the cancer therapy. Studies performed to determine the therapeutic sensitivity and/or resistance after targeting lncRNAs indicated that some lncRNAs mediate therapeutic resistance in different cancer cell types by involving proteins, miRNAs, DNA, and transcription factors $[117,118]$. LncRNAs could serve as chemotherapy-resistance biomarkers, thereby leading to the development of alternative strategies to overcome the disease. BC200 is down-regulated in OC tissue, and carboplatin treatment resulted in increased cell viability, inducing chemoresistance through unknown mechanisms [60]. Future studies will reveal the mechanisms by which BC200 contributes to drug resistance.

HOTAIR is an lncRNA whose influence has been extensively explored in cancer cells presenting therapeutic resistance. In primary OC cells, HOTAIR overexpression and its DNA methylation appeared to induce carboplatin resistance [77], indicating that HOTAIR may contribute to resistance by influencing methylation. In a parallel study, increased HOTAIR expression was observed in the cisplatin-resistant, SKOV-3CDDP/R, ovarian carcinoma cell line model, with subsequent exposure of the cell line to cisplatin upon siRNA-induced knockdown of HOTAIR [16]; this phenomenon was also linked to enhanced apoptosis and cytotoxicity. Another seminal study conducted by Li et al. explored the role of HOTAIR in chemoresistance in OC cells. The study showed that higher expression of HOTAIR in OC cells induced cisplatin resistance through upregulation of the Wnt/ $\beta$-catenin signaling pathway and promoting cell cycle progression. Conversely, inhibition of HOTAIR resulted in cisplatin sensitivity, in vitro and in vivo by suppressing Wnt/ $\beta$-catenin signaling and inducing cell cycle arrest at G1 phase [119]. A recent study performed by Ozes and collogues revealed that HOTIAR mediates chemoresistance in DNA-damage responses through the NF- $\kappa B$ signaling pathway [41]. The multidimensional involvement of HOTAIR in drug resistance may provide a big opportunity to target it for cancer therapy. Similarly, it has been reported that UCA1 upregulation promotes $O C$ cellular viability and induces cellular resistance to cisplatin [103]. In the same study, overexpression of the anti-apoptotic protein serine-arginine protein kinase 1 (SRPK1) was observed; however, cisplatin sensitivity was partially restored following SRPK1 downregulation [103].

Indeed, the interaction of lncRNAs and miRNAs is not limited to the modulation of OC cell progression, but also regulates tumor cell chemosensitivity. For example, zinc finger antisense 1 (ZFAS1) was implicated in tumorigenesis, served as a prognostic biomarker in patients with multiple types of solid tumors [120-122], interacted with miRNA-150$5 \mathrm{p}$, promoted the expression of the specific protein 1 (SP1) gene, and induced OC cellular resistance to cisplatin and paclitaxel [123]. Some lncRNA-mediated resistance mechanisms are represented in Fig. 3.

Another IncRNA, ENST00000457645, was down-regulated in cisplatin-resistant OC cells and abrogated chemoresistance, thereby regulating the expression of downstream target apoptotic proteins [124]. Furthermore, PVT1 overexpression elicited cisplatin resistance in OC cells and contributed to drug resistance by regulating downstream apoptotic proteins [125]. 


\section{Cellular Physiology \begin{tabular}{l|l|l} 
and Biochemistry Published online: November 27, 2017 & $\begin{array}{l}\text { (c) 2017 The Author(s). Published by S. Karger AG, Basel } \\
\text { www.karger.com/cpb }\end{array}$ \\
\hline
\end{tabular}

Fig. 3. LncRNA-mediated drug-resistance mechanisms. Overexpression of HOTIAR mediates drug resistance by activating the $\mathrm{Wnt} / \beta$-catenin signaling pathway and thus sustains OC cell cycle progression. Elevated expression of UCA1 activates SRPK1 and increases the expression of antiapoptotic proteins to promote tumor cell proliferation. ZFAS1 binds to miRNA-150p-5p to regulate the SP1 expression and modulate OC cell chemosensitivity. HOTIAR, hox transcript antisense intergenic RNA; SP1, specific protein 1; SRPK1, serine-arginine protein kinase 1; UCA1, urothelial carcinoma associated 1; ZFAS1, zinc finger antisense 1.

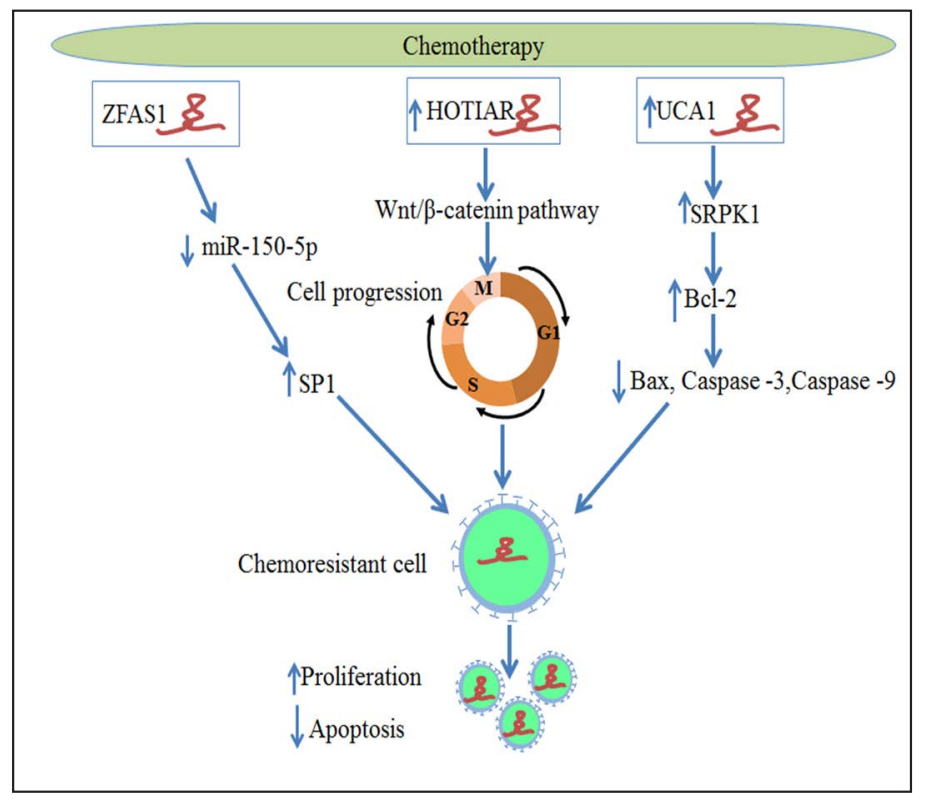

In addition to protein complexes and miRNAs, that associate with lncRNAs during the development of various cancers (including OC), can also mediate drug resistance. For instance, enhancer of zeste homolog 2 (EZH2), a core catalytic subset of PRC2, associates with several oncogenic IncRNAs such as H19, MEG3, HOTAIR, and HEIH [126-128]. EZH2 overexpression promotes invasion and proliferation of OC cells in vitro and tumor growth in vivo and is associated with poor OS. In contrast, siRNA-mediated knockdown of EZH2 impairs oncogenic cell behavior by arresting cell cycle progression [129]. In a separate study, EZH2 expression was elevated in cisplatin-resistant OC cells, but cisplatin resistance was lost upon EZH2 down-regulation [130]. As mentioned above, lncRNAs can strongly regulate OC chemoresistance via their interactions with different partner molecules (Fig. 3).Taken together, these findings strongly suggest that therapeutic approaches should emphasize on combined strategies instead of focusing on single biological molecules, given that cancer initiation and development involves multiple molecules belonging to specific networks, rather than functioning separately.

\section{Conclusion}

LncRNAs are often inscrutable transcriptional products and appear to drive generegulation networks, both in normal and pathological cellular processes. Although many lncRNAs have been identified in the last 10 years, their roles have not been characterized and it is difficult to predict their functions, as they are less amenable to analysis with existing genomic tools. Despite their complexities, the normal cellular roles of some lncRNAs have been reported, but not many functions of lncRNAs have been implicated in malignancy, including that in OC. Continued efforts will unveil the functional contribution of IncRNAs in OC biology.

Of the several remarkable attributes of IncRNAs, their tissue-and/or cell-specific expression patterns and involvement in all steps of OC development are important and should be exploited to develop therapies and biomarkers. Most importantly, the ability of lncRNAs to interact with coding and non-coding transcripts, particularly with miRNAs (Fig. 2 ), is one crossroad that should be focused on during the development of therapies, even though the biogenesis of lncRNAs remains unclear. Further characterization of multiple biogenic pathways of IncRNAs and the molecules involved in these pathways is necessary and will lead to a comprehensive understanding of lncRNAs. As presented in Tables 1 and 


\section{Cellular Physiology Cell Physiol Biochem 2017;44:948-966 \begin{tabular}{l|l|l} 
and: 10.1159/000485395 & $\begin{array}{l}\text { C } 2017 \text { The Author(s). Published by S. Karger AG, Basel } \\
\text { www.karger.com/cpb }\end{array}$
\end{tabular} \\ Worku et al.: LncRNA: Future Biomarker and Therapy}

2 , with few exceptions, most lncRNAs reported in OC are up-regulated both in OC cells and tumor tissue, suggesting that down-regulating their expression is likely to be useful for treating patients. Hence, as mentioned above, RNAi is an important strategy for targeting IncRNAs for therapy, and RNAi-based therapies have been in clinical trials for several years. Interestingly, after much effort, the delivery problem of RNAi-based therapy has been solved [131], and this approach is likely to represent the future gene therapy, although additional work is required for final approval.

Recently, the inhibition of IncRNA loci using CRISPRi technology has garnered attention. Using this approach, Liu et al. inhibited as many as 500 human IncRNA loci [105], and these loci have been found to modify the growth of specific cell types without interfering with neighboring cells. Thus, IncRNA loci, which contribute to cancer development and progression, could be safely targeted for IncRNA-based therapy. Identification of molecules that regulate the transcription (and thus the expression) of lncRNAs is another strategy for targeting lncRNAs. For example, in mouse pluripotent stem cells, Ak028326 and Ak141205 are regulated by the Oct4 and Nanog transcription factors, respectively [132]. The identification of such regulatory molecules might be helpful for targeting lncRNAs. In essence, it might be possible to construct plasmids that can selectively control particular oncogenes and help kill malignant cells. Overall, lncRNAs represent an additional genetic network regulating OC and other genetic disorders by interacting with coding and non-coding molecules and functioning through multiple modes of action via known and unknown pathways. Therefore, further characterization of IncRNAs and their pathways will deepen our understanding and may reveal unforeseen mechanisms, eventually helping to incorporate lncRNAs into future therapies.

\section{Acknowledgements}

The financial support from both the Natural Science Foundation of China (31772602) and the Earmarked Fund for Modern Agro-industry Technology Research System (CARS-3704B) are highly appreciated.

T.W. conceived of this review and wrote the first draft of the manuscript; T.W, D.B, D.A, Z.R., and Y.L. modified the contents and concepts presented in the manuscript; T.W, K.W, C.W, and T.H. designed and created the figures; and T.W and D.A revised the paper. The final version of the manuscript was approved by all authors.

\section{Disclosure Statement}

The authors declare that there is no potential conflict of interest.

\section{References}

1 Jelovac D, Armstrong DK: Recent progress in the diagnosis and treatment of ovarian cancer. CA Cancer J Clin 2011;61:183-203.

2 Prat J: Staging Classification for Cancer of the Ovary, Fallopian Tube, and Peritoneum: Abridged Republication of Guidelines From the International Federation of Gynecology and Obstetrics (FIGO). Int J Gynaecol Obstet 2015;126:171-174.

-3 Qiu JJ, Wang Y, Ding JX, Jin HY, Yang G, Hua KQ: The long non-coding RNA HOTAIR promotes the proliferation of serous ovarian cancer cells through the regulation of cell cycle arrest and apoptosis. Exp Cell Res 2015;333:238-248.

4 Taylor DD, Black PH: Shedding of plasma membrane fragments: Neoplastic and developmental importance. Dev Biol (N Y 1985) 1986;3:33-57. 


\section{Cellular Physiology Cell Physiol Biochem 2017;44:948-966 \begin{tabular}{l|l} 
and Biochemistry $\begin{array}{l}\text { DOI: 10.1159/000485395 } \\
\text { Published online: November 27, } 2017\end{array}$ & $\begin{array}{l}\text { C } 2017 \text { The Author(s). Published by S. Karger AG, Basel } \\
\text { www.karger.com/cpb }\end{array}$ \\
\cline { 1 - 2 }
\end{tabular}}

Worku et al.: LncRNA: Future Biomarker and Therapy

5 Thery C, Ostrowski M, Segura E: Membrane vesicles as conveyors of immune responses. Nat Rev Immunol 2009;9:581-593.

6 Siegel RL, Miller KD, Jemal A: Cancer statistics, 2016. CA Cancer J Clin 2016;66:7-30.

7 Guttman M, Amit I, Garber M, French C, Lin MF, Feldser D, Huarte M, Zuk O, Carey BW, Cassady JP, Cabili MN, Jaenisch R, Mikkelsen TS, Jacks T, Hacohen N, Bernstein BE, Kellis M, Regev A, Rinn JL, Lander ES: Chromatin signature reveals over a thousand highly conserved large non-coding RNAs in mammals. Nature 2009;458:223-227.

-8 Orom UA, Shiekhattar R: Long noncoding RNAs usher in a new era in the biology of enhancers. Cell 2013;154:1190-1193.

9 Prensner JR, Chinnaiyan AM: The emergence of lncRNAs in cancer biology. Cancer Discov 2011;1:391-407.

-10 Gupta RA, Shah N, Wang KC, Kim J, Horlings HM, Wong DJ, Tsai MC, Hung T, Argani P, Rinn JL, Wang Y, Brzoska P, Kong B, Li R, West RB, van de Vijver MJ, Sukumar S, Chang HY: Long non-coding RNA HOTAIR reprograms chromatin state to promote cancer metastasis. Nature 2010;464:1071-1076.

11 Guttman M, Donaghey J, Carey BW, Garber M, Grenier JK, Munson G, Young G, Lucas AB, Ach R, Bruhn L, Yang X, Amit I, Meissner A, Regev A, Rinn JL, Root DE, Lander ES: lincRNAs act in the circuitry controlling pluripotency and differentiation. Nature 2011;477:295-300.

12 Hung T, Wang Y, Lin MF, Koegel AK, Kotake Y, Grant GD, Horlings HM, Shah N, Umbricht C, Wang P, Wang Y, Kong B, Langerod A, Borresen-Dale AL, Kim SK, van de Vijver M, Sukumar S, Whitfield ML, Kellis M, Xiong Y, Wong DJ, Chang HY: Extensive and coordinated transcription of noncoding RNAs within cell-cycle promoters. Nat Genet 2011;43:621-629.

13 Luo M, Jeong M, Sun D, Park HJ, Rodriguez BA, Xia Z, Yang L, Zhang X, Sheng K, Darlington GJ, Li W, Goodell MA: Long non-coding RNAs control hematopoietic stem cell function. Cell Stem Cell 2015;16:426-438.

14 Wu H, Shang X, Shi Y, Yang Z, Zhao J, Yang M, Li Y, Xu S: Genetic variants of lncRNA HOTAIR and risk of epithelial ovarian cancer among Chinese women. Oncotarget 2016;7:41047-41052.

15 Rosa A, Brivanlou AH: Regulatory non-coding RNAs in pluripotent stem cells. Int J Mol Sci 2013;14:1434614373.

16 Wang Y, Wang H, Song T, Zou Y, Jiang J, Fang L, Li P: HOTAIR is a potential target for the treatment of cisplatinresistant ovarian cancer. Mol Med Rep 2015;12:2211-2216.

17 Yang G, Lu X, Yuan L: LncRNA: a link between RNA and cancer. Biochim Biophys Acta 2014;1839:10971109.

18 Pan Y, Li C, Chen J, Zhang K, Chu X, Wang R, Chen L: The Emerging Roles of Long Noncoding RNA ROR (lincRNA-ROR) and its Possible Mechanisms in Human Cancers. Cell Physiol Biochem 2016;40:219-229.

19 Iyer MK, Niknafs YS, Malik R, Singhal U, Sahu A, Hosono Y, Barrette TR, Prensner JR, Evans JR, Zhao S, Poliakov A, Cao X, Dhanasekaran SM, Wu YM, Robinson DR, Beer DG, Feng FY, Iyer HK, Chinnaiyan AM: The landscape of long noncoding RNAs in the human transcriptome. Nat Genet 2015;47:199-208.

20 Meller VH, Joshi SS, Deshpande N: Modulation of Chromatin by Noncoding RNA. Annu Rev Genet 2015;49:673-695.

-21 Saxena A, Carninci P: Long non-coding RNA modifies chromatin: epigenetic silencing by long non-coding RNAs. Bioessays 2011;33:830-839.

22 Hu X, Feng Y, Zhang D, Zhao SD, Hu Z, Greshock J, Zhang Y, Yang L, Zhong X, Wang LP, Jean S, Li C, Huang Q Katsaros D, Montone KT, Tanyi JL, Lu Y, Boyd J, Nathanson KL, Li H, Mills GB, Zhang L: A functional genomic approach identifies FAL1 as an oncogenic long noncoding RNA that associates with BMI1 and represses p21 expression in cancer. Cancer Cell 2014;26:344-357.

-23 Gong C, Maquat LE: IncRNAs transactivate Staufen1-mediated mRNA decay by duplexing with 3'UTRs via Alu elements. Nature 2011;470:284-288.

-24 Beltran M, Puig I, Peña C, García Jé M, Álvarez A, Peña R, Bonilla F, de Herreros A: A natural antisense transcript regulates Zeb2/Sip1 gene expression during Snail1-induced epithelial-mesenchymal transition. Genes Dev 2008;22:756-769.

25 Lai MC, Yang Z, Zhou L, Zhu QQ Xie HY, Zhang F, Wu LM, Chen LM, Zheng SS: Long non-coding RNA MALAT-1 overexpression predicts tumor recurrence of hepatocellular carcinoma after liver transplantation. Med Oncol 2012;29:1810-1816.

-26 Chai Y, Liu J, Zhang Z, Liu L: HuR-regulated lncRNA NEAT1 stability in tumorigenesis and progression of ovarian cancer. Cancer Med 2016;5:1588-1598. 


\section{Cellular Physiology Cell Physiol Biochem 2017;44:948-966 \begin{tabular}{l|l|l|} 
and BOI: 10.1159/000485395 & $\begin{array}{l}\text { C) } 2017 \text { The Author(s). Published by S. Karger AG, Basel } \\
\text { www.karger.com/cpb }\end{array}$
\end{tabular}}

Worku et al.: LncRNA: Future Biomarker and Therapy

27 Meryet-Figuiere M, Lambert B, Gauduchon P, Vigneron N, Brotin E, Poulain L, Denoyelle C: An overview of long non-coding RNAs in ovarian cancers. Oncotarget 2016;7:44719-44734.

28 Parasramka MA, Maji S, Matsuda A, Yan IK, Patel T: Long non-coding RNAs as novel targets for therapy in hepatocellular carcinoma. Pharmacol Ther 2016;161:67-78.

29 Li C, Chen J, Zhang K, Feng B, Wang R, Chen L: Progress and Prospects of Long Noncoding RNAs (lncRNAs) in Hepatocellular Carcinoma. Cell Physiol Biochem 2015;36:423-434.

-30 Wang F, Yang H, Deng Z, Su Y, Fang Q, Yin Z: HOX Antisense lincRNA HOXA-AS2 Promotes Tumorigenesis of Hepatocellular Carcinoma. Cell Physiol Biochem 2016;40:287-296.

-31 Dong L, Ni J, Hu W, Yu C, Li H: Upregulation of Long Non-Coding RNA PlncRNA-1 Promotes Metastasis and Induces Epithelial-Mesenchymal Transition in Hepatocellular Carcinoma. Cell Physiol Biochem 2016;38:836-846.

32 Wang D, Wang D, Wang N, Long Z, Ren X: Long Non-Coding RNA BANCR Promotes Endometrial Cancer Cell Proliferation and Invasion by Regulating MMP2 and MMP1 via ERK/MAPK Signaling Pathway. Cell Physiol Biochem 2016;40:644-656.

-33 Xie W, Yuan S, Sun Z, Li Y: Long noncoding and circular RNAs in lung cancer: advances and perspectives. Epigenomics 2016;8:1275-1287.

34 Wei MM, Zhou GB: Long Non-coding RNAs and Their Roles in Non-small-cell Lung Cancer. Genomics Proteomics Bioinformatics 2016;14:280-288.

-35 Yang ZT, Li Z, Wang XG, Tan T, Yi F, Zhu H, Zhao JP, Zhou XF: Overexpression of Long Non-Coding RNA ZXF2 Promotes Lung Adenocarcinoma Progression Through c-Myc Pathway. Cell Physiol Biochem 2015;35:23602370.

-36 Yan Y, Xu Z, Li Z, Sun L, Gong Z: An Insight into the Increasing Role of LncRNAs in the Pathogenesis of Gliomas. Front Mol Neurosci 2017;10:1-13.

-37 Shi J, Dong B, Cao J, Mao Y, Guan W, Peng Y, Wang S: Long non-coding RNA in glioma: signaling pathways. Oncotarget 2017;8:27582-27592.

38 Luo G, Wang M, Wu X, Tao D, Xiao X, Wang L, Min F, Zeng F, Jiang G: Long Non-Coding RNA MEG3 Inhibits Cell Proliferation and Induces Apoptosis in Prostate Cancer. Cell Physiol Biochem 2015;37:2209-2220.

39 Smolle MA, Bauernhofer T, Pummer K, Calin GA, Pichler M: Current Insights into Long Non-Coding RNAs (LncRNAs) in Prostate Cancer. Int J Mol Sci 2017;18:443.

40 Zhao L, Ji G, Le X, Wang C, Xu L, Feng M, Zhang Y, Yang H, Xuan Y, Yang Y, Lei L, Yang Q Lau WB, Lau B, Chen Y, Deng X, Yao S, Yi T, Zhao X, Wei Y, Zhou S: Long Noncoding RNA LINC00092 Acts in Cancer-Associated Fibroblasts to Drive Glycolysis and Progression of Ovarian Cancer. Cancer Res 2017;77:1369-1382.

-41 Ozes AR, Miller DF, Ozes ON, Fang F, Liu Y, Matei D, Huang T, Nephew KP: NF-kappaB-HOTAIR axis links DNA damage response, chemoresistance and cellular senescence in ovarian cancer. Oncogene 2016;35:5350-5361.

42 Wapinski O, Chang HY: Long noncoding RNAs and human disease. Trends Cell Biol 2011;21:354-361.

43 Qiu H, Wang X, Guo R, Liu Q, Wang Y, Yuan Z, Li J, Shi H: HOTAIR rs920778 polymorphism is associated with ovarian cancer susceptibility and poor prognosis in a Chinese population. Future Oncol 2017;13:347-355.

-44 Richards EJ, Permuth-Wey J, Li Y, Chen YA, Coppola D, Reid BM, Lin HY, Teer JK, Berchuck A, Birrer MJ, Lawrenson K, Monteiro AN, Schildkraut JM, Goode EL, Gayther SA, Sellers TA, Cheng JQ: A functional variant in HOXA11-AS, a novel long non-coding RNA, inhibits the oncogenic phenotype of epithelial ovarian cancer. Oncotarget 2015;6:34745-34757.

45 Xue Y, Gu D, Ma G, Zhu L, Hua Q, Chu H, Tong N, Chen J, Zhang Z, Wang M: Genetic variants in IncRNA HOTAIR are associated with risk of colorectal cancer. Mutagenesis 2015;30:303-310.

-46 Bayram S, Sumbul AT, Batmaci CY, Genc A: Effect of HOTAIR rs 920778 polymorphism on breast cancer susceptibility and clinicopathologic features in a Turkish population. Tumour Biol 2015;36:3863-3870.

-47 Pan W, Liu L, Wei J, Ge Y, Zhang J, Chen H, Zhou L, Yuan Q Zhou C, Yang M: A functional IncRNA HOTAIR genetic variant contributes to gastric cancer susceptibility. Mol Carcinog 2016;55:90-96.

48 Pasmant E, Sabbagh A, Vidaud M, Bieche I: ANRIL, a long, noncoding RNA, is an unexpected major hotspot in GWAS. FASEB J 2011;25:444-448.

49 Beroukhim R, Mermel CH, Porter D, Wei G, Raychaudhuri S, Donovan J, Barretina J, Boehm JS, Dobson J, Urashima M, Mc Henry KT, Pinchback RM, Ligon AH, Cho YJ, Haery L, Greulich H, Reich M, Winckler W, Lawrence MS, Weir BA, Tanaka KE, Chiang DY, Bass AJ, Loo A, Hoffman C, Prensner J, Liefeld T, Gao Q Yecies D, Signoretti S, Maher E, Kaye FJ, Sasaki H, Tepper JE, Fletcher JA, Tabernero J, Baselga J, Tsao MS, 


\section{Cellular Physiology Cell Physiol Biochem 2017;44:948-966 \begin{tabular}{l|l|l|}
\hline DOI: 10.1159/000485395 & $\begin{array}{l}\text { C) } 2017 \text { The Author(s). Published by S. Karger AG, Basel } \\
\text { www.karger.com/cpb }\end{array}$
\end{tabular}}

Worku et al.: LncRNA: Future Biomarker and Therapy

Demichelis F, Rubin MA, Janne PA, Daly MJ, Nucera C, Levine RL, Ebert BL, Gabriel S, Rustgi AK, Antonescu CR, Ladanyi M, Letai A, Garraway LA, Loda M, Beer DG, True LD, Okamoto A, Pomeroy SL, Singer S, Golub TR, Lander ES, Getz G, Sellers WR, Meyerson M: The landscape of somatic copy-number alteration across human cancers. Nature 2010;463:899-905.

50 Stuart D, Sellers WR: Linking somatic genetic alterations in cancer to therapeutics. Curr Opin Cell Biol 2009;21:304-310.

51 Du Z, Fei T, Verhaak RGW, Su Z, Zhang Y, Brown M, Chen Y, Liu XS: Integrative genomic analyses reveal clinically relevant long non-coding RNA in human cancer. Nat Struct Mol Biol 2013;20:908-913.

52 Liu H, Li J, Koirala P, Ding X, Chen B, Wang Y, Wang Z, Wang C, Zhang X, Mo YY: Long non-coding RNAs as prognostic markers in human breast cancer. Oncotarget 2016;7:20584-20596.

53 Ji P, Diederichs S, Wang W, Boing S, Metzger R, Schneider PM, Tidow N, Brandt B, Buerger H, Bulk E, Thomas M, Berdel WE, Serve H, Muller-Tidow C: MALAT-1, a novel noncoding RNA, and thymosin beta4 predict metastasis and survival in early-stage non-small cell lung cancer. Oncogene 2003;22:8031-8041.

54 Ma X-Y, Wang J-H, Wang J-L, Ma CX, Wang X-C, Liu F-S: Malat1 as an evolutionarily conserved lncRNA, plays a positive role in regulating proliferation and maintaining undifferentiated status of early-stage hematopoietic cells. BMC Genomics 2015;16:676.

55 Zhou Y, Xu X, Lv H, Wen Q, Li J, Tan L, Li J, Sheng X: The Long Noncoding RNA MALAT-1 Is Highly Expressed in Ovarian Cancer and Induces Cell Growth and Migration. PLoS One 2016;11:1-14.

56 Liu S, Jiang X, Li W, Cao D, Shen K, Yang J: Inhibition of the long non-coding RNA MALAT1 suppresses tumorigenicity and induces apoptosis in the human ovarian cancer SKOV3 cell line. Oncol Lett 2016;11:3686-3692.

57 Zou A, Liu R, Wu X: Long non-coding RNA MALAT1 is up-regulated in ovarian cancer tissue and promotes SK-OV-3 cell proliferation and invasion. Neoplasma 2016;63:865-872.

58 Shiga K, Hara M, Nagasaki T, Sato T, Takahashi H, Takeyama H: Cancer-Associated Fibroblasts: Their Characteristics and Their Roles in Tumor Growth. Cancers (Basel) 2015;7:2443-2458.

59 Luo Z, Wang Q Lau WB, Lau B, Xu L, Zhao L, Yang H, Feng M, Xuan Y, Yang Y, Lei L, Wang C, Yi T, Zhao X, Wei Y, Zhou S: Tumor microenvironment: The culprit for ovarian cancer metastasis? Cancer Lett 2016;377:174182.

60 Wu DI, Wang T, Ren C, Liu L, Kong D, Jin X, Li X, Zhang G: Downregulation of BC200 in ovarian cancer contributes to cancer cell proliferation and chemoresistance to carboplatin. Oncol Lett 2016;11:11891194.

61 Li J, Huang H, Li Y, Li L, Hou W, You Z: Decreased expression of long non-coding RNA GAS5 promotes cell proliferation, migration and invasion, and indicates a poor prognosis in ovarian cancer. Oncol Rep 2016;36:3241-3250.

62 Huang S, Qing C, Huang Z, Zhu Y: The long non-coding RNA CCAT2 is up-regulated in ovarian cancer and associated with poor prognosis. Diagn Pathol 2016;11:49.

-63 Qiu JJ, Lin YY, Ding JX, Feng WW, Jin HY, Hua KQ: Long non-coding RNA ANRIL predicts poor prognosis and promotes invasion/metastasis in serous ovarian cancer. Int J Oncol 2015;46:2497-2505.

64 Li J, Yu H, Xi M, Lu X: Long noncoding RNA C17orf91 is a potential prognostic marker and functions as an oncogene in ovarian cancer. J Ovarian Res 2016;9:49.

65 Kuang D, Zhang X, Hua S, Dong W, Li Z: Long non-coding RNA TUG1 regulates ovarian cancer proliferation and metastasis via affecting epithelial-mesenchymal transition. Exp Mol Pathol 2016;101:267-273.

66 Yim GW, Kim HJ, Kim LK, Kim SW, Kim S, Nam EJ, Kim YT: Long Non-coding RNA HOXA11 Antisense Promotes Cell Proliferation and Invasion and Predicts Patient Prognosis in Serous Ovarian Cancer. Cancer Res Treat 2017;49:656-668.

67 Li H, Liu C, Lu Z, Chen L, Wang J, Li Y, Ma H: Upregulation of the long non-coding RNA SPRY4-IT1 indicates a poor prognosis and promotes tumorigenesis in ovarian cancer. Biomed Pharmacother 2017;88:529-534.

-68 Yu J, Han Q, Cui Y: Decreased long non-coding RNA SPRY4-IT1 contributes to ovarian cancer cell metastasis partly via affecting epithelial-mesenchymal transition.Tumour Biol 2017;39. Doi:1010428317709129.

69 Cheng Z, Guo J, Chen L, Luo N, Yang W, Qu X: A long noncoding RNA AB073614 promotes tumorigenesis and predicts poor prognosis in ovarian cancer. Oncotarget 2015;6:25381-25389.

70 Zou A, Liu R, Wu X: Long non-coding RNA MALAT1 is up-regulated in ovarian cancer tissue and promotes SK-OV-3 cell proliferation and invasion. Neoplasma 2016;63:865-872. 


\section{Cellular Physiology Cell Physiol Biochem 2017;44:948-966 \begin{tabular}{l|l|l} 
and Biochemistry 10.1159/000485395 & $\begin{array}{l}\text { (c) 2017 The Author(s). Published by S. Karger AG, Basel } \\
\text { www.karger.com/cpb }\end{array}$ \\
\hline Published online: November 27, 2017
\end{tabular}}

Worku et al.: LncRNA: Future Biomarker and Therapy

-71 Zhang X, Li S, Dong C, Xie X, Zhang Y: Knockdown of long noncoding RNA NR_026689 inhibits proliferation and invasion and increases apoptosis in ovarian carcinoma HO-8910PM cells. Oncol Res 2017;25:259-265.

72 Gu Y, Chen T, Li G, Yu X, Lu Y, Wang H, Teng L: LncRNAs: emerging biomarkers in gastric cancer. Future Oncol 2015;11:2427-2441.

73 Wang L, Chen Z, An L, Wang Y, Zhang Z, Guo Y, Liu C: Analysis of Long Non-Coding RNA Expression Profiles in Non-Small Cell Lung Cancer. Cell Physiol Biochem 2016;38:2389-2400.

74 Mouraviev V, Lee B, Patel V, Albala D, Johansen TE, Partin A, Ross A, Perera RJ: Clinical prospects of long noncoding RNAs as novel biomarkers and therapeutic targets in prostate cancer. Prostate Cancer Prostatic Dis 2016;19:14-20.

75 Huang R, Wang X, Zhang W, Zhangyuan G, Jin K, Yu W, Xie Y, Xu X, Wang H, Sun B: Down-Regulation of LncRNA DGCR5 Correlates with Poor Prognosis in Hepatocellular Carcinoma. Cell Physiol Biochem 2016;40:707-715.

-76 Hong H, Hou L, Pan X, Wu C, Huang H, Li B, Nie W: Long non-coding RNA UCA1 is a predictive biomarker of cancer. Oncotarget 2016;7:44442-44447.

-77 Teschendorff AE, Lee SH, Jones A, Fiegl H, Kalwa M, Wagner W, Chindera K, Evans I, Dubeau L, Orjalo A, Horlings HM, Niederreiter L, Kaser A, Yang W, Goode EL, Fridley BL, Jenner RG, Berns EM, Wik E, Salvesen HB, Wisman GB, van der Zee AG, Davidson B, Trope CG, Lambrechts S, Vergote I, Calvert H, Jacobs IJ, Widschwendter M: HOTAIR and its surrogate DNA methylation signature indicate carboplatin resistance in ovarian cancer. Genome Med 2015;7:108.

78 Luo P, Liu XF, Wang YC, Li ND, Liao SJ, Yu MX, Liang CZ, Tu JC: Prognostic value of abnormally expressed lncRNAs in ovarian carcinoma: a systematic review and meta-analysis. Oncotarget 2017;8:23927-23936.

-79 Chen Z, Zhang Z, Xie B, Zhang H: Clinical significance of up-regulated lncRNA NEAT1 in prognosis of ovarian cancer. Eur Rev Med Pharmacol Sci 2016;20:3373-3377.

80 Zhou M, Sun Y, Sun Y, Xu W, Zhang Z, Zhao H, Zhong Z, Sun J: Comprehensive analysis of IncRNA expression profiles reveals a novel IncRNA signature to discriminate nonequivalent outcomes in patients with ovarian cancer. Oncotarget 2016;7:32433-32448.

81 Martini P, Paracchini L, Caratti G, Mello-Grand M, Fruscio R, Beltrame L, Calura E, Sales G, Ravaggi A, Bignotti E, Odicino FE, Sartori E, Perego P, Katsaros D, Craparotta I, Chiorino G, Cagnin S, Mannarino L, Ceppi L, Mangioni C, Ghimenti C, D’Incalci M, Marchini S, Romualdi C: IncRNAs as Novel Indicators of Patients' Prognosis in Stage I Epithelial Ovarian Cancer: A Retrospective and Multicentric Study. Clin Cancer Res 2017;23:2356-2366.

82 Hu X, Bao J, Wang Z, Zhang Z, Gu P, Tao F, Cui D, Jiang W: The plasma IncRNA acting as fingerprint in nonsmall-cell lung cancer. Tumour Biol 2016;37:3497-3504.

83 Tang Q, Ni Z, Cheng Z, Xu J, Yu H, Yin P: Three circulating long non-coding RNAs act as biomarkers for predicting NSCLC. Cell Physiol Biochem 2015;37:1002-1009.

-84 Li J, Wang X, Tang J, Jiang R, Zhang W, Ji J, Sun B: HULC and Linc00152 Act as Novel Biomarkers in Predicting Diagnosis of Hepatocellular Carcinoma. Cell Physiol Biochem 2015;37:687-696.

-85 Qiu ZL, Shen CT, Sun ZK, Wei WJ, Zhang XY, Song HJ, Luo QY: Circulating Long Non-Coding RNAs Act as Biomarkers for Predicting 131I Uptake and Mortality in Papillary Thyroid Cancer Patients with Lung Metastases. Cell Physiol Biochem 2016;40:1377-1390.

86 Hu HB, Jie HY, Zheng XX: Three Circulating LncRNA Predict Early Progress of Esophageal Squamous Cell Carcinoma. Cell Physiol Biochem 2016;40:117-125.

87 Wu Y, Wang YQ, Weng WW, Zhang QY, Yang XQ Gan HL, Yang YS, Zhang PP, Sun MH, Xu MD, Wang CF: A serum-circulating long noncoding RNA signature can discriminate between patients with clear cell renal cell carcinoma and healthy controls. Oncogenesis 2016;5:e192.

88 Griffiths-Jones S: The microRNA Registry. Nucleic Acids Res 2004;32:D109-111.

89 Griffiths-Jones S: miRBase: the microRNA sequence database. Methods Mol Biol 2006;342:129-138.

90 Pal MK, Jaiswar SP, Dwivedi VN, Tripathi AK, Dwivedi A, Sankhwar P: MicroRNA: a new and promising potential biomarker for diagnosis and prognosis of ovarian cancer. Cancer Biol Med 2015;12:328-341.

-91 Berindan-Neagoe I, Monroig Pdel C, Pasculli B, Calin GA: MicroRNAome genome: a treasure for cancer diagnosis and therapy. CA Cancer J Clin 2014;64:311-336.

92 Cho WC: MicroRNAs: potential biomarkers for cancer diagnosis, prognosis and targets for therapy. Int J Biochem Cell Biol 2010;42:1273-1281. 


\section{Cellular Physiology Cell Physiol Biochem 2017;44:948-966 \begin{tabular}{l|l|l}
\hline and BOI: 10.1159/000485395 & $\begin{array}{l}\text { C } 2017 \text { The Author(s). Published by S. Karger AG, Basel } \\
\text { www.karger.com/cpb }\end{array}$
\end{tabular}}

Worku et al.: LncRNA: Future Biomarker and Therapy

93 Sulaiman SA, Ab Mutalib NS, Jamal R: miR-200c Regulation of Metastases in Ovarian Cancer: Potential Role in Epithelial and Mesenchymal Transition. Front Pharmacol 2016;7:271.

$\$ 94$ Yan L, Zhou J, Gao Y, Ghazal S, Lu L, Bellone S, Yang Y, Liu N, Zhao X, Santin AD, Taylor H, Huang Y: Regulation of tumor cell migration and invasion by the H19/let-7 axis is antagonized by metformininduced DNA methylation. Oncogene 2015;34:3076-3084.

95 Ma Y, Lu Y, Lu B: MicroRNA and Long Non-Coding RNA in Ovarian Carcinoma: Translational Insights and Potential Clinical Applications. Cancer Invest 2016;34:465-476.

-96 Zhou X, Ye F, Yin C, Zhuang Y, Yue G, Zhang G: The Interaction Between MiR-141 and lncRNA-H19 in Regulating Cell Proliferation and Migration in Gastric Cancer. Cell Physiol Biochem 2015;36:1440-1452.

$\$ 97$ Wang Y, Chen F, Zhao M, Yang Z, Li J, Zhang S, Zhang W, Ye L, Zhang X: The long noncoding RNA HULC promotes liver cancer by increasing the expression of the HMGA2 oncogene via sequestration of the microRNA-186. J Biol Chem 2017;292:15395-15407.

-98 Rodriguez A, Griffiths-Jones S, Ashurst JL, Bradley A: Identification of mammalian microRNA host genes and transcription units. Genome Res 2004;14:1902-1910.

99 Gao Y, Meng H, Liu S, Hu J, Zhang Y, Jiao T, Liu Y, Ou J, Wang D, Yao L, Liu S, Hui N: LncRNA-HOST2 regulates cell biological behaviors in epithelial ovarian cancer through a mechanism involving microRNA let-7b. Hum Mol Genet 2015;24:841-852.

100 Zhang Z, Cheng J, Wu Y, Qiu J, Sun Y, Tong X: LncRNA HOTAIR controls the expression of Rab22a by sponging miR-373 in ovarian cancer. Mol Med Rep 2016;14:2465-2472.

101 Nishimura M, Jung EJ, Shah MY, Lu C, Spizzo R, Shimizu M, Han HD, Ivan C, Rossi S, Zhang X, Nicoloso MS, Wu SY, Almeida MI, Bottsford-Miller J, Pecot CV, Zand B, Matsuo K, Shahzad MM, Jennings NB, RodriguezAguayo C, Lopez-Berestein G, Sood AK, Calin GA: Therapeutic synergy between microRNA and siRNA in ovarian cancer treatment. Cancer Discov 2013;3:1302-1315.

-102 Ho TT, Zhou N, Huang J, Koirala P, Xu M, Fung R, Wu F, Mo YY: Targeting non-coding RNAs with the CRISPR/ Cas9 system in human cell lines. Nucleic Acids Res 2015;43:e17.

103 Wang F, Zhou J, Xie X, Hu J, Chen L, Hu Q, Guo H, Yu C: Involvement of SRPK1 in cisplatin resistance related to long non-coding RNA UCA1 in human ovarian cancer cells. Neoplasma 2015;62:432-438.

104 Zhu S, Li W, Liu J, Chen C-H, Liao Q, Xu P, Xu H, Xiao T, Cao Z, Peng J, Yuan P, Brown M, Liu XS, Wei W: Genome-scale deletion screening of human long non-coding RNAs using a paired-guide RNA CRISPR-Cas 9 library. Nat Biotechnol 2016; 34:1279-1286.

105 Liu SJ, Horlbeck MA, Cho SW, Birk HS, Malatesta M, He D, Attenello FJ, Villalta JE, Cho MY, Chen Y, Mandegar MA, Olvera MP, Gilbert LA, Conklin BR, Chang HY, Weissman JS, Lim DA: CRISPRi-based genome-scale identification of functional long noncoding RNA loci in human cells. Science 2017;355. Doi:10.1126/ science.aah7111.

106 Wu H, Shang X, Shi Y, Yang Z, Zhao J, Yang M, Li Y, Xu S: Genetic variants of IncRNA HOTAIR and risk of epithelial ovarian cancer among Chinese women.Oncotarget 2016;7:41047-41052.

107 Goyal A, Myacheva K, Gross M, Klingenberg M, Duran Arque B, Diederichs S: Challenges of CRISPR/Cas9 applications for long non-coding RNA genes. Nucleic Acids Res 2017;45:e12.

108 Li W, Teng F, Li T, Zhou Q: Simultaneous generation and germline transmission of multiple gene mutations in rat using CRISPR-Cas systems. Nat Biotechnol 2013;31:684-686.

109 Fujii W, Kawasaki K, Sugiura K, Naito K: Efficient generation of large-scale genome-modified mice using gRNA and CAS9 endonuclease. Nucleic Acids Res 2013;41:e187-e187.

110 Matouk IJ, Raveh E, Abu-lail R, Mezan S, Gilon M, Gershtain E, Birman T, Gallula J, Schneider T, Barkali M, Richler C, Fellig Y, Sorin V, Hubert A, Hochberg A, Czerniak A: Oncofetal H19 RNA promotes tumor metastasis. Biochim Biophys Acta 2014;1843:1414-1426.

111 Kawakami T, Zhang C, Taniguchi T, Kim CJ, Okada Y, Sugihara H, Hattori T, Reeve AE, Ogawa O, Okamoto K: Characterization of loss-of-inactive $\mathrm{X}$ in Klinefelter syndrome and female-derived cancer cells. Oncogene 2004;23:6163-6169.

112 Sheng X, Li J, Yang L, Chen Z, Zhao Q, Tan L, Zhou Y, Li J: Promoter hypermethylation influences the suppressive role of maternally expressed 3 , a long non-coding RNA, in the development of epithelial ovarian cancer. Oncol Rep 2014;32:277-285.

113 Tan J, Yang X, Zhuang L, Jiang X, Chen W, Lee PL, Karuturi RK, Tan PB, Liu ET, Yu Q: Pharmacologic disruption of Polycomb-repressive complex 2-mediated gene repression selectively induces apoptosis in cancer cells. Genes Dev 2007;21:1050-1063. 


\section{Cellular Physiology Cell Physiol Biochem 2017;44:948-966 \begin{tabular}{l|l|l}
\hline and Biochemistry 10.1159/000485395 & $\begin{array}{l}\text { C) } 2017 \text { The Author(s). Published by S. Karger AG, Basel } \\
\text { www.karger.com/cpb }\end{array}$ \\
\hline
\end{tabular}}

Worku et al.: LncRNA: Future Biomarker and Therapy

114 Knutson SK, Wigle TJ, Warholic NM, Sneeringer CJ, Allain CJ, Klaus CR, Sacks JD, Raimondi A, Majer CR, Song J, Scott MP, Jin L, Smith JJ, Olhava EJ, Chesworth R, Moyer MP, Richon VM, Copeland RA, Keilhack H, Pollock RM, Kuntz KW: A selective inhibitor of EZH2 blocks H3K27 methylation and kills mutant lymphoma cells. Nat Chem Biol 2012;8:890-896.

115 McCabe MT, Ott HM, Ganji G, Korenchuk S, Thompson C, Van Aller GS, Liu Y, Graves AP, Della Pietra A, 3rd, Diaz E, LaFrance LV, Mellinger M, Duquenne C, Tian X, Kruger RG, McHugh CF, Brandt M, Miller WH, Dhanak D, Verma SK, Tummino PJ, Creasy CL: EZH2 inhibition as a therapeutic strategy for lymphoma with EZH2activating mutations. Nature 2012;492:108-112.

116 Qi W, Chan H, Teng L, Li L, Chuai S, Zhang R, Zeng J, Li M, Fan H, Lin Y, Gu J, Ardayfio O, Zhang JH, Yan X, Fang J, Mi Y, Zhang M, Zhou T, Feng G, Chen Z, Li G, Yang T, Zhao K, Liu X, Yu Z, Lu CX, Atadja P, Li E: Selective inhibition of Ezh2 by a small molecule inhibitor blocks tumor cells proliferation. Proc Natl Acad Sci U S A 2012;109:21360-21365.

117 Deng H, Zhang J, Shi J, Guo Z, He C, Ding L, Tang JH, Hou Y: Role of long non-coding RNA in tumor drug resistance. Tumor Biol 2016;37:11623-11631.

118 Ayers D, Vandesompele J:Influence of microRNAs and Long Non-Coding RNAs in Cancer Chemoresistance. Genes (Basel) 2017;8:95.

119 Li J, Yang S, Su N, Wang Y, Yu J, Qiu H, He X: Overexpression of long non-coding RNA HOTAIR leads to chemoresistance by activating the Wnt/beta-catenin pathway in human ovarian cancer. Tumour Biol 2016;37:2057-2065.

120 Liu F, Gao H, Li S, Ni X, Zhu Z: Long non-coding RNA ZFAS1 correlates with clinical progression and prognosis in cancer patients. Oncotarget 2017;8:61561-61569.

121 Lan T, Lan X, Li G, Zheng Z, Zhang M, Qin F: Prognostic role of long noncoding RNA ZFAS1 in cancer patients: a systematic review and meta-analysis. Oncotarget2017. Doi:10.18632/oncotarget.19162.

122 Song W, Tian C, Zhang RJ, Zou SB, Wang K: Meta-Analysis of the prognostic value of lncRNA ZFAS1 in patients with solid tumors. Oncotarget 2017. Doi:10.18632/oncotarget.19566.

123 Xia B, Hou Y, Chen H, Yang S, Liu T, Lin M, Lou G: Long non-coding RNA ZFAS1 interacts with miR-150-5p to regulate Sp1 expression and ovarian cancer cell malignancy.Oncotarget 2017;8:19534-19546.

124 Yan H, Xia JY, Feng FZ: Long non-coding RNA ENST00000457645 reverses cisplatin resistance in CP70 ovarian cancer cells. Genet Mol Res 2017;16.

125 Liu E, Liu Z, Zhou Y, Mi R, Wang D: Overexpression of long non-coding RNA PVT1 in ovarian cancer cells promotes cisplatin resistance by regulating apoptotic pathways. Int J Clin Exp Med 2015;8:20565-20572.

126 Yang F, Zhang L, Huo XS, Yuan JH, Xu D, Yuan SX, Zhu N, Zhou WP, Yang GS, Wang YZ, Shang JL, Gao CF, Zhang FR, Wang F, Sun SH: Long noncoding RNA high expression in hepatocellular carcinoma facilitates tumor growth through enhancer of zeste homolog 2 in humans. Hepatology 2011;54:1679-1689.

127 Zhao J, Ohsumi TK, Kung JT, Ogawa Y, Grau DJ, Sarma K, Song JJ, Kingston RE, Borowsky M, Lee JT: Genomewide identification of polycomb-associated RNAs by RIP-seq. Mol Cell 2010;40:939-953.

128 Tsai MC, Manor O, Wan Y, Mosammaparast N, Wang JK, Lan F, Shi Y, Segal E, Chang HY: Long noncoding RNA as modular scaffold of histone modification complexes. Science 2010;329:689-693.

129 Rao ZY, Cai MY, Yang GF, He LR, Mai SJ, Hua WF, Liao YJ, Deng HX, Chen YC, Guan XY, Zeng YX, Kung HF, Xie D: EZH2 supports ovarian carcinoma cell invasion and/or metastasis via regulation of TGF-beta1 and is a predictor of outcome in ovarian carcinoma patients. Carcinogenesis 2010;31:1576-1583.

$130 \mathrm{Hu}$ S, Yu L, Li Z, Shen Y, Wang J, Cai J, Xiao L, Wang Z: Overexpression of EZH2 contributes to acquired cisplatin resistance in ovarian cancer cells in vitro and in vivo. Cancer Biol Ther 2010;10:788-795.

131 Dowdy SF: Overcoming cellular barriers for RNA therapeutics. Nat Biotechnol 2017;35:222-229.

132 Sheik Mohamed J, Gaughwin PM, Lim B, Robson P, Lipovich L: Conserved long noncoding RNAs transcriptionally regulated by Oct4 and Nanog modulate pluripotency in mouse embryonic stem cells. Rna 2010;16:324-337. 